\title{
Optimization of Palmitic Acid Composition in Crude Oleic Acid to Provide Specifications of Titer and Cloud Point of Distillate Oleic Acid using a Flash Distiller
}

\author{
Muhammad Yusuf Ritonga ${ }^{1}$
}

\begin{abstract}
Titer and cloud point of Distilled Oleic Acid is higher than is the standard on feed composition palmitic acid (C15H31COOH) or C16 $11.2 \%$. Feed composition C16, top temperature precut and bottom main distiller column were optimized to produce DOA. A factorial design with 3 independent variables, $3 \times 2 \times 3$, repeated twice as much, is applied to observe effects of feed composition $\mathrm{C} 16$ to quality parameters. In the optimum C16, feed composition at $5.20 \%$ produced DOA with titer $6.8{ }^{\circ} \mathrm{C}$, cloud point $5.0{ }^{\circ} \mathrm{C}$ (inside its specification).
\end{abstract}

Keywords- $\mathbf{C 1 6}$ composition, distillation, top temperature precut, bottom temperature main distiller, titer, cloud point

\section{INTRODUCTION}

$\mathrm{O}$ leochemical industries have just established in Indonesia since 1988 and begun the operations in the last following 2 years. At that time, oleochemical was a new industry in our country and we still relied on the power of the overseas technology even for daily operations. Along with the development of oleochemical industries, Indonesia has become more aware of how to control daily operations, how to change or modify the oprating condition, and how to make modifications better in quality and diversification for better product so tht the industries can complete in international markets and win the demand.

Optimization results in this article is one indicator of the ability of Indonesia in the form of modifying, refining and diversifying new products in this industry, particularly manufacturing and purifying DOA of CPO to manufacture and purify Distillate Oleic Acid (DOA) of crude palm oil (CPO). This is the first one in Indonesia; furthermore starting from 2004, the products have reached international standard. This research was conducted by using distillation facilities of PT. XXX, the only manufacturer of DOA in Indonesia which has so far been used as the standard conditions for distillation of productions and purifications of DOA (Fig. 1 and Fig. 2). The results of this study would enable Indonesia to minimize the dependency towards other countries' capacities. Until 2005, the DOA quality has not yet met the standards of the overall qualities, including that of titer and cloud points, and this causes inefficient productions, including

\footnotetext{
${ }^{1}$ Muhammad Yusuf Ritonga is with Department of Chemical Engineering, FT, Jl. Almamater Kampus Universitas Sumatera Utara, Medan, 20155, Indonesia. E-mail: yusufrit@gmail.com.
}

relatively low production of DOA, wastefully use of energy consumption and low competitiveness in the markets of oleochemical industry, as a consequence, the level of income would subsequently decrease; therefore, it is feasible to optimize for better efficiency and profitability.

The distillation of raw material process was generated from dry fractionation crude palm oil based. This is called the Crude Oleic Acid (CAO) [5]. Distillation process was used due to a distillation process since the COA contains lower and higher boiling points, such as: short chain of fatty acids, hydrocarbons, aldehydes and/or ketones, pigments and odors, and also triglyceride which can be separated well by distillation under vacuum pressure so that the quality of the product is better and more stable [1$3,7,10,12,15]$.

The applied main conditions of crude oleic acid distillation process at that time were $11.2 \%$ level of C16 feed, feed flow rate of $4.0 \mathrm{mt} / \mathrm{hr}$, while the temperature of the top precut column was between 216-219 ${ }^{0} \mathrm{C}$ at a pressure of $21-25 \mathrm{mbar}$, and the temperature of the bottom main or flash distiller column was between $246-249{ }^{\circ} \mathrm{C}$ at a pressure of $10-12$ mbar and flow rate DOA $3360 \mathrm{mt} / \mathrm{hr}$.

That distillation process conditions produced titer 12.7 and cloud point $9.9{ }^{\circ} \mathrm{C}$ (it was lower than the desired quality standards) [5] and the yield of main products DOA was generally low, $84.0 \%(3360 \mathrm{~kg} /$ hr) (the desired was higher, approaching 90\%); $7.3 \%$ yield residue (292 $\mathrm{kg} / \mathrm{hr}$ ) (was less desirable) and feed only $4.0 \mathrm{mt} / \mathrm{hr}$ maximum (the desired was much higher than $4.0 \mathrm{mt} / \mathrm{hr}$ ).

This fact becomes an evidence that the plant has not been able to follow the trends in the oleochemicals industry over the past 30 years, which produced highquality final products with a high yield as well [7, 10].

DOA production in 2002 was 2400 tons and continued up to 7200 tons in 2005 . The increasing in the average demand of DOA within 2002-2005 is 1,600 tons per year [5]. This also becomes a factor that contributes to this research. This production is relatively lasted until 2007, because of the dry fractionation plant capacity that was limited only to produce of crude oleic acid (COA).

Palm oil was not only used as a source of saturated fatty acids: palmitic acid $\left(\mathrm{C}_{15} \mathrm{H}{ }_{30} \mathrm{COOH}\right)$ or $\mathrm{C}_{18}$ and stearic acid $\left(\mathrm{C}_{17} \mathrm{H}_{34} \mathrm{COOH}\right)$ or $\mathrm{C}_{18}$, but it was also used as a source of unsaturated fatty acid oleic acid 
$\left(\mathrm{C}_{17} \mathrm{H}_{33} \mathrm{COOH}\right)$ or $\mathrm{C}_{18-1}$ and linoleic acid $\left(\mathrm{C}_{17} \mathrm{H}_{32} \mathrm{COOH}\right)$ or $\mathrm{C}_{18-2}$ (Table 2). Palm oil also contains a short carbon chain of fatty acids, hydrocarbons, aldehydes and/or ketones, pigments and odors-called impurities are too sensitive to heat or the heating $[10,12]$, these impurities remain ended into COA (Fig.1), which also determines the stages, the conditions of purification and quality of DOA because there are relations among the processes.

In hydrolysis CPO triglyceride was converted into SCPOFA (Splitted Crude Palm Fatty Acid) which had slightly higher color from the color of crude palm oil, due to high heating $\left(250-260{ }^{\circ} \mathrm{C}\right)$ during hydrolysis, so that the color of impurities will be darker, but the composition is relatively similar to CPO (Table 2). This will greatly affect the quality of the COA for DOA distillation, manufacture and purification. To manufacture and purify DOA lauric, myristic, palmitic (as the biggest components) and stearic acid must be separated into lower initial concentration so that the oleic acid concentration of DOA will be higher. The problem is how it can be separated and what process of technology will be applied on the present facilities.

This research aims to create a DOA with $70 \%$ minimum oleic acid composition,that is better and more efficient than is the existing facilities. In determining the direction of research, two boundaries between the quality parameters (titer and cloud point) that do not fit the standard are required (Table 1).

Titer is the solidification point of fatty acid determined under specific condition. The titer value can be correlated with the degree of unsaturated of fatty acid and is useful determination for identifying and purifying fatty acid [13].

Cloud point an alternative of the titer of an unsaturated fatty acid is the temperature at which a cloud or haze of crystal appears when the fatty acid is chilled without disturbance under definite prescribed conditions. It also correlates with the degree of unsaturated of fatty acid [13]. The higher the degree and amount of unsaturated fatty acid in fatty acid sample is, the lower the titer and the cloud point of fatty acid sample will be.

Reducing the amount of palmitic acid also reduces the amount of lauric acid $\left(\mathrm{C}_{11} \mathrm{H}_{22} \mathrm{COOH}\right)$, myristic $\left(\mathrm{C}_{13} \mathrm{H}_{26} \mathrm{COOH}\right)$ and stearic $\left(\mathrm{C}_{17} \mathrm{H}_{34} \mathrm{COOH}\right)$. Reducing the amount of palmitic acid becomes the main staple in raising levels of unsaturated fatty acids, oleic acid on the COA and DOA. Refining the existing distillation facilities can not be done, because only if it consists of the precut column to separate the light end (lauric acid, myristate, hydrocarbons, aldehydes and/or ketones, pigments, and the odors of a lower boiling point) and the main or flash distiller do not use trays and only demister (Fig. 8), so that no fractionation can be made, (although based on the value of the boiling point of fatty acids in Table 3 it is still possible to do so), only separating the mixture of fatty acids (palmitic, stearic, oleic and linoleic acid) from the residue (the mixture of CPO triglyceride, arachidic acid, hydrocarbons, aldehides or ketones, pigments and odors) (Fig. 2). The residue has the higher boiling point. If distillation facility consists of at least 2 or a maximum three fractionation columns, the manufacturing and purifying DOA (70\% w / w minimum) will be affordable (See the boiling point of some fatty acids associated with the purifying DOA within Table 3 ).

Based on the fact above and melting point value of each fatty acid in Table 4, decreasing palmitic acid composition is still possible to be made through a fractionation by crystallization in dry fractionation unit, to increase oleic acid content in COA (compare Table 5 and compare with Table 2). This will produce COA with lower titer and cloud point and the optimum one should be used as distillation feed. It can be found by researching and optimization. So the route to manufacture and purify DOA should be employed as mentioned in Fig. 1 above.

Through this step some impurities were separated into COA and stearic acid blended, so precut column's load was lower to separate palmitic acid and the lower fatty acids of oleic acid. Its capacity will be higher also and should be higher and optimum one capacity also. It can be found by researching and optimization also.

The composition of the feed becomes primary consideration in analyzing the possibilities of research steps that must be done in distilliation [8, 11, 14]. It includes COA, especially changes in the composition of palmitic acid $\left(\mathrm{C}_{15} \mathrm{H}_{30} \mathrm{COOH}\right)$ and its relationship with the direction of changes in the composition of stearic, oleic and linoleic acid, in particular the quality of DOA parameters, especially both titer and cloud point quality also refining conditions that will be applied to the distillation, based on the quality standards of DOA.

Decreasing palmitic acid concentration of COA will decrease the concentration of stearic $\left(\mathrm{C}_{17} \mathrm{H}_{34} \mathrm{COOH}\right)$, lauric, myristic acid and increase the major unsaturated fatty acid concentration with the longer carbon chain, such as oleic acid $\left(\mathrm{C}_{17} \mathrm{H}_{33} \mathrm{COOH}\right)$ in DOA, through distillation (considered of each fatty acid boiling point in Table 3). This will affect into decreasing of the titer and cloud point of DOA, because of oleic acid had the lowest freezing point than all the others fatty acids in DOA, except linoleic acid (see Table 4 ). Linoleic acid (with 2 double bonds of $\mathrm{C}=\mathrm{H}$ ) has the lower freezing point than oleic acid (with one double bond of $\mathrm{C}=\mathrm{H}$ ), because of the additional of the double bond of fatty acid affect to the lower freezing point [13]. The varied reducing of palmitic acid concentration will produce DOA with the lower varies titer and cloud point, should be any the optimum one for the titer and cloud point of DOA that meet its quality standard. It can be found by researching and optimization. Based on this, results will be obtained also an idea to modify the present facility.

Based on the melting also freezing point values in Table 4 and boiling point in Table 3 , it is so interesting to decrease all of fatty acids content under oleic acid to reduce the titer and cloud point of COA and DOA, but it is not possible, because each fatty acid dissolved to each other and made the difficulties in the separation using crystallization that cannot be separated completely). The lower the fatty acid content in feed, 
the more difficult it is to be separated. Therefore, decreasing palmitic acid will remain the same as other fatty acids, but with lower concentration.

In distillation, decreasing palmiatic acid is not possible either, although it is done through fractional distillation to get the lower titer and cloud of DOA. A suitable fractionation column could not reach $100 \%$ effectiveness for the separation, including the separation of other fatty acids under oleic acid, although it will be lower compared to the uses in the present flash distiller. Besides the boiling point of stearic acid was so close to the boiling point of oleic acid (Table 3 ) and the amount of stearic, palmitic, myristic and lauric were small enough in the feed (Table 5). Thus, this is the reason why decreasing of palmitic acid will remain the same as other fatty acids, with lower concentration, although through distillation.

\section{METHOD}

Raw material, crude oleic acid, was produced by fractionation of Splitted Crude Palm Oil Fatty Acid (SCPOFA) from Dry Fractionation Plant (SCPOFA as a Crude Fatty Acid that was produced by crude palm oil hydrolysis). Crude oleic acid will be purified. Soft water was produced from water treatment plant, steam 11 bars from the Steam Medium Pressure Boiler (SMP Boiler) and Oil Thermal Heater (OTH) from the OTH Boiler. All of these are available on PT. XXX's plant site.

Research used the factorial method with 3 independent variables, such as level of $\mathrm{C}_{16}$ feed at level of 5.2, 7.7 and $10.5 \%$ by weight, the top temperature of the precut column at 190 and $195^{\circ} \mathrm{C}$ (15-21 mbar pressure) and the bottom temperature of main distiller column at 218,220 and $220^{\circ} \mathrm{C}$ (pressure of 5 mbar) at a feed flow rate of 5 tons / hour. Factorial method was planned with a fixed model $3 \times 2 \times 3$ and repeated 2 times for each factor [13] and the parameters were observed, among others, are the titer, cloud point and changes in the production levels of DOA. Statistical analysis was performed with the program of Minitab release 14 [9]. Samples of DOA were taken every 2 hours, minimum of $500 \mathrm{ml}$ and analysed with the procedure of analysis refers to AOCS 1-62 for fatty acid composition analysis, AOCS Ce 13e-92 for analysis of the titer and AOCS Ce 13e-92 for analysis of the cloud point of DOA [4].

\section{RESULTS AND DISCUSSION}

This optimization has resulted in the 1280.16 tonnes appropriate quality standards DOA. Decreasing levels of $\mathrm{C}_{16}$ feed on Table 6 caused a decreasing in the value of feed titer and cloud-point. The influence on increasing of production and decreasing in value of the titer and the point cloud of DOA are shown in Table 7. These data on this TABLE show the decline in the titer, cloud point and the higher production levels of DOA that are the effect of decreasing of $\mathrm{C}_{16}$ levels of the feed. These statements are the results of factorial method analysis that was used in this research.

\section{A. The Signification of the Effect of the Optimized Process Variables On the Titer of DOA}

In analyzing the effect of process variables with Minitab Release $14 ; \mathrm{C}_{16}$ is $\mathrm{C}_{16}$ content in the feed, $\mathrm{T}$ precut is the top temperature of the precut column and B. MD is the bottom temperature of of the main or flash distiller column, a * between the two symbols of this process variable state of the interaction between two or more variables. So $\mathrm{C}_{16} * \mathrm{~T}$ precut, is the interaction levels of $\mathrm{C}_{16}$ feed with the top temperature of precut column and so on for the others interaction, $d f$ is degrees of freedom, Jk is sum of square, $\mathrm{kt}$ is central square, $\mathrm{F}_{\text {Anova }}$ is distribution test analysis of variance and $\mathrm{P}_{\text {Anova }}$ is significance test analysis of variance. Effect of process variables, significant, if $\mathrm{P}_{\text {anova }}<\mathrm{P} \alpha$ $=0.05$.

Factorial analysis results in Table 8 and the signification in Table 9 below described the influence of optimized process variables on the titer of DOA. The statistical analysis results on Table 8 and its signification in Table 9 shows that the levels of $\mathrm{C}_{16}$ and the top temperature of the precut column effect is significant on the titer of DOA $\left(\mathrm{P}_{\text {anova }}<\mathrm{P} \alpha\right)$, while the bottom temperature of the main or flash distiller column effect is not significant $\left(\mathrm{P}_{\text {anova }}>\mathrm{P} \alpha\right)$.

The impact of each main factor's shown in Fig. 3 below. The reduction of $\mathrm{C}_{16}$ increases the composition of $\mathrm{C}_{18-1}$ DOA at the same temperature of the top precut and the bottom main or flash distiller column. Raising in the top temperature of the precut column caused a decline of $\mathrm{C}_{16}$ which increase of $\mathrm{C}_{18-1}$ DOA, so that the titer is much lower because of oleic acid $\left(\mathrm{C}_{18-1}\right)$ has lower titer than the titer of saturated fatty acids $\mathrm{C}_{12}$, $\mathrm{C}_{14}, \mathrm{C}_{16}$ and $\mathrm{C}_{18}$ also $\mathrm{C}_{20}$ [14].

Raising the bottom temperature of the main or flash distiller column do not significantly affect the levels of changing of $\mathrm{C}_{18-1}$ DOA, it doesn't significantly affect to the lower titer of DOA. See Table 7 above.

Based on the data and figures above, suitable optimum conditions for the purification of DOA are at $5.2 \%$ level of $\mathrm{C}_{16}$ in the feed, the top temperatures of the precut column at $195{ }^{\circ} \mathrm{C}$ and $222^{\circ} \mathrm{C}$ on the bottom temperature of the main or flash distiller column (i.e the highest DOA production at this temperature, see Table 7 above).

1. The Effect of C16 Levels in the Feed and Top Temperature of Precut Column to the Titer of DOA

Decreasing $C_{16}$ feed leads $C_{18-1}$ level of the feed to increase (Table 6) and increasing the temperature of the top precut column causes $\mathrm{C}_{16}$ evaporate more in the same column, which also causes of increasing of level of $\mathrm{C}_{18-1}$ in the DOA (Table 7). This leads lower titer values of DOA.Based on the summary results of statistical analysis one way ANOVA in Table 10 and graphic of the interaction of the main factors in Fig. 4 (graph 1) below.

Decreased levels of $\mathrm{C}_{16}$ in the feed at the top temperature of the precut column of 190 and $195^{\circ} \mathrm{C}$ lead the lower titer of DOA, a significant influence, be 
cause $\mathrm{P}_{\text {anova }}=0.000<\mathrm{P} \alpha$. The increment of the top temperature of the precut column at the same level $\mathrm{C}_{16}$ in the feed cause of the lower titer of DOA, a significant effect, because $\mathrm{P}_{\text {anova }}=0.000$. See Fig. 5 below, at the point $(5.2,4444.36)$.

The lowest titer of DOA is obtained at $5.2 \%$ by weight of $\mathrm{C}_{16}$ feed at a top temperature of the precut column at 190 and $195^{\circ} \mathrm{C}$, but the highest DOA production is obtained at $5.2 \%$ of $\mathrm{C}_{16}$ level in the feed and the top temperature of the precut column at $195{ }^{\circ} \mathrm{C}$ (Table 7 above), which are summarized in Fig. 5.

2. The Effect of C16 Levels in the Feed and BottomTemperature of Main Distiller to the Titer of DOA

Based on Fig. 4 (graph 2), the reduction in titer DOA due to the increment of the bottom temperature of the main distiller at the same level of $\mathrm{C}_{16}$ in the feed is not significant. As a result the interaction between the decreasing of level of $\mathrm{C}_{16}$ in the feed and the increment of the bottom temperature of the main or flash distiller is not significant either. This is caused by the increment level of $\mathrm{C}_{18-1}$ of DOA that is relatively small changes and not constant at the increment of the bottom temperature of the main or flash distiller on the same level of $\mathrm{C}_{16}$ in the feed (Table 7).

The mean titer of DOA as a result of the interaction of these two factors is shown in the summary of statistical analysis using one way ANOVA in Table 11 below, reinforce the results of significance in Table 9 , Fig. 3, Fig. 4 (graph 2) and Fig. 5.

The statistical results depicted in Table 11 can be explained as follows: interaction effect of the bottom temperature increment of main or flash distiller on the same $\mathrm{C}_{16}$ feed does not significantly decrease titer of DOA, because relatively small changes are not permanent; however, this interaction causes bigger head given off to separate DOA so it is easier that the DOA becomes evaporated and condensed. The results from the interaction of these two factors are processed and taken flat rating of DOA increment and are summarized in Fig. 6, on the right hand column of this page.

The biggest production of DOA was obtained at 5.2 $\%$ level of $\mathrm{C}_{16}$ in the feed and $222{ }^{\circ} \mathrm{C}$ on the bottom temperature of the main or flash distiller, because the average level of $\mathrm{C}_{18-1}$ is the largest at this point (Table 7 ), which cause the lowest average titer of DOA and the largest average of DOA production. The optimum conditions are selected in the lowest titer of DOA and the largest of DOA production.

Based on the above discussion, the optimum conditions to reduce the titer of DOA are $5.2 \%$ level of $\mathrm{C}_{16}$ in the feed, the top temperature of the precut column $195^{\circ} \mathrm{C}$ and the bottom temperature of the main or flash distiller column $222^{\circ} \mathrm{C}$.

Before the optimization's carried out, the efforts to reduce the titer performed with the addition of $\mathrm{C}_{12}$ and $\mathrm{C}_{14}$ to reduce level of $\mathrm{C}_{16}$. Reducing $\mathrm{C}_{16}$ content will reduce the titer of DOA.

\section{B. The Effect of Process Variables Optimized and Its Interaction to the Cloud Point of DOA}

Statistical analysis results in Table 12 and signification in TABLE 13 show that the level of $\mathrm{C}_{16}$ feed has a significant influence on the cloud point of DOA $\left(\mathrm{P}_{\text {anova }}=0.00<\mathrm{P} \alpha=0.05\right)$, the top temperature of the precut column's significant $\left(\mathrm{P}_{\mathrm{anova}}=0.00<\mathrm{P} \alpha=0.05\right)$, the influence of the bottom temperature of the main or flash distiller column's also significant with $\left(\mathrm{P}_{\text {anova }}=\right.$ $0023<P \alpha=0.05)$.

The final results of statistical analysis show the decreasing factor $\mathrm{C}_{16}$ feed, increment of the top temperature of the precut column and a significant interaction influence of the decreasing in the cloud point (cp) DOA. The results of factorial statistical analysis, graphic plots of the main factors and their interactions as well as summary results of statistical analysis using one-way ANOVA below are sufficient to be used as distillation data to discuss the optimum conditions of DOA purification in this study. The effects of the main factors are shown in Fig. 7.

Decreasing $\mathrm{C}_{16}$ levels affects the increasing levels of $\mathrm{C}_{18-1}$ DOA at the same top temperature precut and the main or flash distiller column (see Table 7 above, on $1^{\text {st }}-5^{\text {th }}$ column). The increasing of the top temperature of precut column caused a decreasing in $\mathrm{C}_{16}$ which causes the increasing of $\mathrm{C}_{18-1}$ DOA, so that the cloud point is significantly lower. This is due to oleic acid $\left(\mathrm{C}_{18-1}\right)$ that has the lowest freezing point than saturated fatty acids $\mathrm{C}_{12}, \mathrm{C}_{14}, \mathrm{C}_{16}$ and $\mathrm{C}_{18}$ also $\mathrm{C}_{20}$ [13].

Based on the data and figures above, the suitable optimum conditions for the purification of DOA are at $5.2 \%$ level of $\mathrm{C}_{16}$ in the feed, the top temperatures of precut column of $195^{\circ} \mathrm{C}$ and the bottom temperatures of the main or flash distiller at $222{ }^{\circ} \mathrm{C}$ (remember the highest production of DOA at this temperature, see Table 7 and Fig. 5).

a. The Effect of $\mathrm{C}_{16}$ Levels of feed and the Top Temperature Precut Column to the Cloud Point of DOA

Decreasing $\mathrm{C}_{16}$ feed lead to increase level of $\mathrm{C}_{18-1}$ (Table 7) and increasing the top temperature of the precut column causing $\mathrm{C}_{16}$ is evaporated more on the same column, which also causes the increasing level of $\mathrm{C}_{18-1}$ in the DOA. This leads to the lower value of the DOA cloud point.

Based on the summary results of statistical analysis one way ANOVA on Table 14 below and graphic plots interaction among the main factors in Fig. 8 (graphic 1) above, decreasing level of $\mathrm{C}_{16}$ in the feed at the top temperature of the precut column at 190 and $195{ }^{\circ} \mathrm{C}$, cause the lower cloud point of DOA, significant effect, because $\mathrm{P}_{\text {anova }}=0.000$.

The incrasing of the top temperature of the precut column at the same level of $\mathrm{C}_{16}$, which also causes the lower cloud point of DOA, significant effect, because $\mathrm{P}_{\text {anova }}=0.000$. The lowest cloud point of DOA was obtained at $5.2 \%$ of $\mathrm{C}_{16}$ in the feed better at a temperature of 190 and $195{ }^{\circ} \mathrm{C}$, but the highest production of DOA is obtained at $5.2 \% \mathrm{C}_{16}$ feed and 
the top temperature of the precut column $195{ }^{\circ} \mathrm{C}$ (Table 7), which are summarized in Fig. 5, at the point (5.2, 4444.36). By watching carefully Table 14, the lowest cloud point of DOA is obtained at $5.533{ }^{\circ} \mathrm{C}$. This value is obtained at $195{ }^{\circ} \mathrm{C}$ of the top temperature of the precut column.

Based on the data and figures above, the suitable optimum conditions for the purification of DOA are at $5.2 \%$ of $\mathrm{C}_{16}$ level in the feed and at $195{ }^{\circ} \mathrm{C}$ for the top temperatures of the precut column.

b. The Effect of C16 Levels in the Feed and the Bottom Temperature Main Distiller to the Cloud Point of DOA

Based on Fig. 8 (graph 2), decreasing of cloud point DOA is due to increasing of the bottom temperature of the main or flash distiller column at the same level of $\mathrm{C}_{16}$ feed as a result of a significant interaction between decreasing level of $\mathrm{C}_{16}$ feed and the bottom temperature of the main or flash distiller column. This is caused by increasing level of $\mathrm{C}_{18-1}$ DOA, changes up relatively to the increment of the bottom temperature of the main or flash distiller column at the same level of $\mathrm{C}_{16}$ feed (Table 7 above) that causes the average of cloud point of DOA is $5.4{ }^{\circ} \mathrm{C}$, as the lowest at $222{ }^{\circ} \mathrm{C}$ of the bottom temperature of the main or flash distiller column (see Table 15).

The average value of cloud-point of DOA, as a result of the interaction of two factors is shown in the summary of statistical analysis using one way ANOVA in Table 15 above, reinforce the results of significance in Table 8, Fig. 7, Fig. 8 (graph 2) and Fig. 6.

The statistical results in Table 15 can be explained as follows: interaction effect of the increasing of the bottom temperature of the main or flash distiller at the same level of $\mathrm{C}_{16}$ feed is significantly affect to the decreasing of cloud point of DOA.

The largest DOA production is obtained at level $5.2 \%$ of $\mathrm{C}_{16}$ feed and the bottom temperature of the main or flash distiller $222{ }^{\circ} \mathrm{C}$, because of the average level of $\mathrm{C}_{18-1}$ is the largest at this point. See Fig. 4, Fig. 5 and (Table 7) above, which causes of the DOA average production is greater and lowest cloud point. The optimum conditions were selected at the lowest cloud point and the largest DOA.

Based on the above data, it can be inferred that there are suitable conditions for the purification of DOA, at $5.2 \%$ of $\mathrm{C} 16$ level in feed (COA), the top temperature of the precut column $195{ }^{\circ} \mathrm{C}$ and the bottom temperature of the main or flash distiller column $222^{\circ}$ $\mathrm{C}$ with the lowest cloud point $5.40^{\circ} \mathrm{C}$.

Before the optimization efforts to reduce the cloud point is done by adding $\mathrm{C}_{12}$ (lauric acid) and $\mathrm{C}_{14}$ (miristic acid) to reduce level of $\mathrm{C}_{16}$. Getting down $\mathrm{C}_{16}$ content will reduce the cloud point of DOA.

\section{Comparation of Optimization Results}

The results of the optimization can be seen in Table 16 and Table 17. The optimum conditions of oleic acid purification through distillation can be performed on a feed capacity of $5 \mathrm{mt} /$ hour with a higher production level of DOA at $88.34 \%$. It is higher than $84.0 \%$.
DOA quality that is produced according to the quality standard within Table 1 . The titer of DOA is obtained at $6.8{ }^{\circ} \mathrm{C}$ and the cloud point at $5.0{ }^{\circ} \mathrm{C}$. These values are lower than the the standard (Table 7 in the bottom row).

D. An Idea to Modify the Present Distillation Technology for Better Oleic Acid Purification

Based on these results (see the increment of oleic acid composition cause of the increment of bottom temperature of the main distiller in TABLE 7 above), the refining technology available in the existing facilities can be improved, in order to improve the quality of oleic acid with a certain color and odor (both not discussed in this article), composition (mainly oleic acid $\mathrm{C}_{18-1}$ greater than the results of this study) and the production yield of DOA. See Fig. 10 [5]. Titer and cloud point value will be better than the results of this study.

The present main or flash distiller (see Fig. 9) has no tray, but only demister. It cannot separate palmitic acid to the lower to provide oleic acid $\mathrm{C}_{18-1}$ composition to the higher. Improvement of this equipment will expand the capacity of oleic acid purification through distillation, and it has also better quality of DOA and higher capability to compete in the market of oleochemical industry.

Replacement of the main or flash distiller column with the main fractionator ( $2^{\text {nd }}$ column in Fig. 10) with the special trays (that has a higher efficiency) and double condensers or partial condensers will increase the efficiency of separation of the lower boiling point and higher boiling point of DOA, the impurities that had been mentioned in introduction above. The separation of palmitic acid would be more effective and it composition will be lower, so the composition of oleic acid will be higher than the results of this study (80\% minimum). Reduction of palmitic acid will be accompanied by the better color, odor and the bigger yield of DOA. Replacement of total condenser in the present main distiller with partial condenser will be easier to separate the impurities light end, colors, odors so that DOA quality will be better stable. The impurities cannot be separated bigger on the top of $1^{\text {st }}$ column, because of heat stress effect in $1^{\text {st }}$ column, heat stress affects the darker of color and stronger odor of fatty acid products, including DOA.

\section{CONCLUSIONS}

The optimum conditions for oleic acid purification through distillation process to provide the in specs titer and cloud point DOA as quality standard are at $5.2 \%$ of $\mathrm{C}_{16}$ feed, the top temperature of the precut column $195{ }^{\circ} \mathrm{C}$ and the bottom temperature of the main or flash distiller column $222{ }^{\circ} \mathrm{C}$, which is appropriate to increase production yield of DOA to be $88.34 \%$ (higher than $84 \%)$ also to reduce the titer $\left(6.8^{\circ} \mathrm{C}\right)$ and cloud point $\left(5.0^{\circ} \mathrm{C}\right) \mathrm{DOA}$.

In general, it can be concluded that there are three major refining process variables were optimized in this experiment. Declining $\mathrm{C}_{16}$ level in the feed, increasing the top temperature of the precut column and the bot 
IPTEK, The Journal for Technology and Science, Vol. 21, No. 4, November 2010

tom temperature of the main or flash distiller column had the significant influences on the decreasing of the titer and the cloud point also on the increasing of DOA production yield, which met the quality standards of DOA in Table 1 above.

\section{SUGGESTIONS}

Production yield of DOA of has the possibility to get higher by using crude oleic acid with the lower $\mathrm{C}_{16}$ in the feed, lower than $5.2 \%$. It is also possible to modify the present facility of distillation to get the higher oleic acid purity by using the suitable fractionation column with double condensers (partial condenser) as replacement of the main or flash distiller with total condenser.

\section{REFERENCES}

[1] Bernardini, 1985, "Oil seeds oils and fats", $2^{\text {nd }}$ Edition, Vol. II, B.E Oil Publishing House, Roma.

[2] R. Brocmann, G. Demmering, U. Kreutzer, M. Lindeman, J. Plachinka, U. Steihrner, 1987, "Fatty acid", Henkel KGaA, Dusseldorf, Federal Republic of German.

[3] H. Brown, 1979, "New fatty acids from outer space", JAOCS, Vol. 56, pp. 729-732A.

[4] F. David, 2006, "Official Methode And Recommended Practices of the Journal of the American Oil Chemists Society", $5^{\text {th }}$ Edition, $2^{\text {nd }}$ Printing, AOCS Press, USA.
[5] Flora Sawita Chemindo, 2005, "Production planning control", Medan, Indonesia.

[6] E. Fritz, 1979, "Interrelationships in fatty acid processing", Journal of the American Oil Chemists Society, Vol.56, pp. 744A-745A.

[7] A. E. S. Hermann, 1990, "Fractionation/ Distillation : improvement in quality, efficiency, energy and environmental aspects", Proceeding World Confrence on Oleochemicals into $21^{s t}$ Century, Kuala Lumpur.

[8] Y. R. Muhammad, 1996, "Distillasi praktis II", Program Studi Teknik Kimia, Fakultas Teknik, Universitas Sumatera Utara.

[9] Nur Iriawan, Septin Puji Astuti, 2006, "Mengolah data statistik dengan mudah menggunakan minitab 14", Penerbit Andi, Yokyakarta.

[10] W. Peter, Faesler, Karl Kolmezt, Wang Seng Kek, 2004, "Revamp strategies for fatty acid distillation section in oleochemical plants", Sulzer Chemtech, Singapore.

[11] Prieto Gonzalez, M. M., J.C. Bada, Leon M., E. Graciani, 2007, "Optimization of deacidification of mixture of sunflower oil and oleic acid in a continuous process", Journal of the American Oil Chemists Society, Vol. 84 (5).

[12] Muhammad Yusuf Ritonga, 2006, "Distillasi asam oleat dari minyak inti kelapa sawit”, Jurnal Saintek, Vol. 23 (2), pp. 55 58, ITM, Medan.

[13] Unichema International, 1998, "Fatty acid data book", $2^{\text {nd }}$ Edition, Unichema, Republic of German.

[14] T. Wang, L. Jhonson, 2001,"Refining high-free fatty acid wheat germ oil", Journal of the American Oil Chemists Society, Vol. 78 (1), pp. 71.

[15] K.T. Zilch, 1979, "Separation of fatty acids", Journal of the American Oil Chemists Society, Vol. 56, pp. 739A-742A.

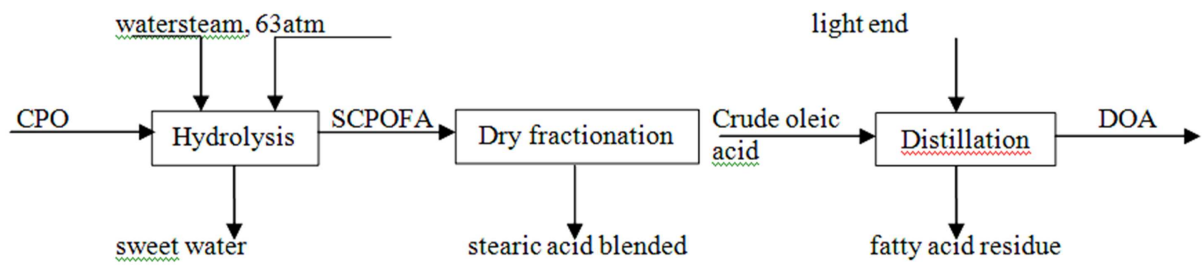

Fig. 1. Block diagram to convert $\mathrm{CPO}$ in manufacturing and purifying DOA

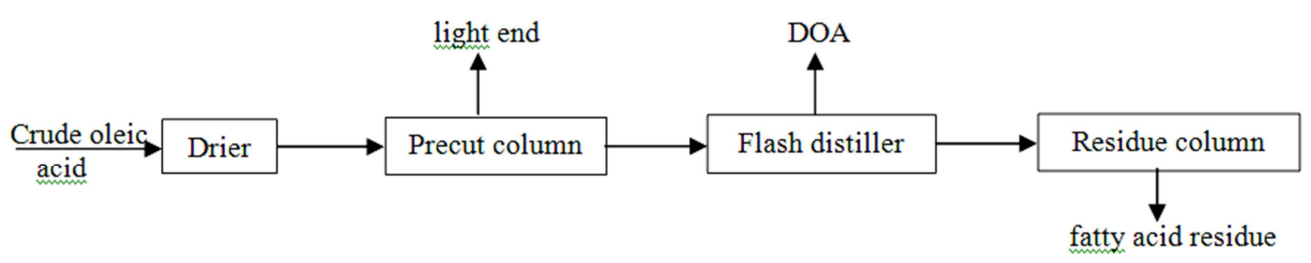

Fig. 2. Block diagram of distillation of manufacturing and purifying DOA

TABLE 1.

DOA QUALITY STANDARD AND QUALITY BEFORE OPTIMIZATION

\begin{tabular}{clcc}
\hline No & \multicolumn{1}{c}{ Quality Parameters } & $\begin{array}{c}\text { Quality } \\
\text { Standards }\end{array}$ & $\begin{array}{c}\text { DOA Quality before } \\
\text { Optimization }\end{array}$ \\
\hline 1 & Composition, \% w/w: & & \\
& $\mathrm{C}_{18-1}$, oleic acid & $70 \mathrm{~min}$ & 71.1 \\
2 & Titer $\left({ }^{\circ} \mathrm{C}\right)$ & $10 \mathrm{max}$ & 12.7 \\
3 & Cloud point $(\mathrm{Cp})\left({ }^{\circ} \mathrm{C}\right)$ & $8 \mathrm{max}$ & 9.9 \\
\hline
\end{tabular}

TABLE 2.

FATTY ACIDS COMPOSITION RANGE IN CRUDE PALM OIL

\begin{tabular}{cccccc}
\hline No & $\begin{array}{c}\text { Fatty acids } \\
\text { name }\end{array}$ & $\begin{array}{c}\text { Total } \\
\text { Carbon }\end{array}$ & $\begin{array}{c}\text { Amount of } \\
\text { Double Bond }\end{array}$ & Symbol & $\begin{array}{c}\text { Composition } \\
(\% \mathrm{w} / \mathrm{w})\end{array}$ \\
\hline 1 & Lauric acid & $\mathrm{C}_{12}$ & 0 & $\mathrm{C}_{12}$ & $1 \mathrm{max}$ \\
2 & Myristic acid & $\mathrm{C}_{14}$ & 0 & $\mathrm{C}_{14}$ & $2 \mathrm{max}$ \\
3 & Palmitic acid & $\mathrm{C}_{16}$ & 0 & $\mathrm{C}_{16}$ & $43-47$ \\
4 & Stearic acid & $\mathrm{C}_{18}$ & 0 & $\mathrm{C}_{18}$ & $3-6$ \\
5 & Oleic acid & $\mathrm{C}_{18}$ & 1 & $\mathrm{C}_{18}$ & $35-45$ \\
6 & Linoleic acid & $\mathrm{C}_{18}$ & 2 & $\mathrm{C}_{18}$ & $9-11$ \\
7 & Arachidic acid & $\mathrm{C}_{20}$ & 0 & $\mathrm{C}_{20}$ & $1 \mathrm{max}$ \\
\hline Source: PT. Flora Sawita Chemindo $(2005)$ & & &
\end{tabular}

Source: PT. Flora Sawita Chemindo (2005) 
IPTEK, The Journal for Technology and Science, Vol. 21, No. 4, November 2010

TABLE 3.

FATTY ACIDSBOILING POINT AT10 MMHG

\begin{tabular}{clccc}
\hline No & \multicolumn{1}{c}{ Name } & Symbol & Chemical Formula & $\begin{array}{c}\text { Boiling } \\
\text { Point }\left({ }^{\circ} \mathrm{C}\right)\end{array}$ \\
\hline 1 & Lauric acid & $\mathrm{C}_{12}$ & $\mathrm{C}_{11} \mathrm{H}_{22} \mathrm{COOH}$ & 166.0 \\
2 & Myristic acid & $\mathrm{C}_{14}$ & $\mathrm{C}_{13} \mathrm{H}_{26} \mathrm{COOH}$ & 190.8 \\
3 & Palmitic acid & $\mathrm{C}_{16}$ & $\mathrm{C}_{15} \mathrm{H}_{30} \mathrm{COOH}$ & 205.8 \\
4 & Stearic acid & $\mathrm{C}_{18}$ & $\mathrm{C}_{17} \mathrm{H}_{34} \mathrm{COOH}$ & 225.0 \\
5 & Oleic acid & $\mathrm{C}_{18-1}$ & $\mathrm{C}_{17} \mathrm{H}_{33} \mathrm{COOH}$ & 223.0 \\
6 & Linoleic acid & $\mathrm{C}_{18-2}$ & $\mathrm{C}_{17} \mathrm{H}_{32} \mathrm{COOH}$ & 224.0 \\
\hline
\end{tabular}

TABLE 4 .

FATTY ACIDS MELTING POINT

\begin{tabular}{clcccc}
\hline No & Name & Symbol & $\begin{array}{c}\text { Chemical } \\
\text { Formula }\end{array}$ & $\begin{array}{c}\text { Melting point } \\
\left({ }^{\circ} \mathrm{C}\right)\end{array}$ & $\begin{array}{c}\text { Freezing Point } \\
\left({ }^{\circ} \mathrm{C}\right)\end{array}$ \\
\hline 1 & Lauric acid & $\mathrm{C}_{12}$ & $\mathrm{C}_{11} \mathrm{H}_{22} \mathrm{COOH}$ & 44.0 & 0.85 \\
2 & Myristic acid & $\mathrm{C}_{14}$ & $\mathrm{C}_{13} \mathrm{H}_{26} \mathrm{COOH}$ & 54.0 & 0.70 \\
3 & Palmitic acid & $\mathrm{C}_{16}$ & $\mathrm{C}_{15} \mathrm{H}_{30} \mathrm{COOH}$ & 62.5 & 0.60 \\
4 & Stearic acid & $\mathrm{C}_{18}$ & $\mathrm{C}_{17} \mathrm{H}_{34} \mathrm{COOH}$ & 69.8 & 0.5 \\
5 & Oleic acid & $\mathrm{C}_{18-1}$ & $\mathrm{C}_{17} \mathrm{H}_{33} \mathrm{COOH}$ & $13.5 ; 16.3$ & $?$ \\
6 & Linoleic acid & $\mathrm{C}_{18-2}$ & $\mathrm{C}_{17} \mathrm{H}_{32} \mathrm{COOH}$ & -5.0 & $?$ \\
\hline
\end{tabular}

1) Source: Unichema International, 1998

TABLE 5 .

\begin{tabular}{|c|c|c|}
\hline No & Analisis Items & $\begin{array}{c}\text { Quality } \\
\text { Range }\end{array}$ \\
\hline \multirow[t]{7}{*}{1} & Oleic acid composition, $\% \mathrm{w} / \mathrm{w}$ & \\
\hline & $\mathrm{C}_{12}$, Lauric acid & $0.5-0.8$ \\
\hline & $\mathrm{C}_{14}$, Miristic acid & $1.0-6.4$ \\
\hline & $\mathrm{C}_{16}$, Palmitic acid & $6.7-15.4$ \\
\hline & $\mathrm{C}_{18}$, Stearic acid & $1.2-3.0$ \\
\hline & $\mathrm{C}_{18-1}$, Oleic acid & $61.3-69.9$ \\
\hline & $\mathrm{C}_{18-2}$, Linoleic acid & $17.2-22.2$ \\
\hline 2 & Color $51 / 4$ " lovibond & $\begin{array}{c}(14.3-19.7) \mathrm{R} / \\
(35.3-70) \mathrm{y} /(4.7-11) \mathrm{B}\end{array}$ \\
\hline 3 & Iodine value & $90-101$ \\
\hline 4 & Titer $\left({ }^{\circ} \mathrm{C}\right)$ & $>10$ \\
\hline 5 & Cloud Point $\left({ }^{\circ} \mathrm{C}\right)$ & $>8$ \\
\hline
\end{tabular}

TABLE 6.

CRude Oleic Acid Feed (COA) Quality After Optimization

\begin{tabular}{ccccc}
\hline \multirow{2}{*}{ No } & Quality & \multicolumn{3}{c}{$\mathrm{C}_{16}$ Concentration, \% w/w } \\
& Parameter & 10.5 & 7.7 & 5.2 \\
\hline 1 & Titer $\left({ }^{\circ} \mathrm{C}\right)$ & 18.20 & 15.3 & 8.2 \\
2 & $\mathrm{Cp}\left({ }^{\circ} \mathrm{C}\right)$ & 15.60 & 12.4 & 7.2 \\
3 & Composition & & & \\
& $(\% \mathrm{w} / \mathrm{w})$ & & & \\
& $\mathrm{C}_{12}$ & 0.70 & 0.2 & 0.3 \\
& $\mathrm{C}_{14}$ & 1.40 & 1.2 & 1.2 \\
& $\mathrm{C}_{16}$ & 10.50 & 7.7 & 5.2 \\
& $\mathrm{C}_{18}$ & 2.40 & 1.6 & 1.3 \\
& $\mathrm{C}_{18-1}$ & 66.20 & 70.8 & 72.9 \\
& $\mathrm{C}_{18-2}$ & 17.20 & 17.6 & 18.3 \\
& $\mathrm{C}_{20}$ & 0.70 & 0.2 & 0.2 \\
& Unk & 0.90 & 0.7 & 0.7 \\
\hline
\end{tabular}

TABLE 7.

Average Value of $\mathrm{C}_{18-1}$ Composition, Production, Titer and Cloud Point DoA

\begin{tabular}{|c|c|c|c|c|c|c|c|}
\hline \multirow{2}{*}{ No } & \multirow{2}{*}{$\begin{array}{l}\mathrm{C}_{16} \mathrm{COA} \\
\% \mathrm{w} / \mathrm{w}\end{array}$} & \multicolumn{2}{|c|}{ Temperature $\left({ }^{\circ} \mathrm{C}\right)$} & \multirow{2}{*}{$\begin{array}{c}\overline{C 18-1} \\
\% \mathrm{w} / \mathrm{w}\end{array}$} & \multirow{2}{*}{$\begin{array}{c}\text { DOA } \\
\text { (kg/hours) }\end{array}$} & \multirow{2}{*}{$\begin{array}{c}\overline{\text { Titer }} \\
\left({ }^{\circ} \mathrm{C}\right)\end{array}$} & \multirow{2}{*}{$\begin{array}{c}\overline{\text { Cloud po }} \\
\left({ }^{\circ} \mathrm{C}\right)\end{array}$} \\
\hline & & Topprecut & Bottom MD & & & & \\
\hline \multirow{6}{*}{1} & \multirow{6}{*}{$10.5 \%$} & \multirow{3}{*}{190} & 218 & 68.25 & 4088.85 & 17.85 & 15.40 \\
\hline & & & 220 & 68.35 & 4110.05 & 18.05 & 15.45 \\
\hline & & & 222 & 68.35 & 4127.06 & 18.3 & 15.70 \\
\hline & & \multirow{3}{*}{195} & 218 & 68.55 & 4120.90 & 16.5 & 13.20 \\
\hline & & & 220 & 68.75 & 4157.77 & 16.3 & 13.00 \\
\hline & & & 222 & 68.95 & 4196.11 & 16.35 & 13.05 \\
\hline \multirow{6}{*}{2} & \multirow{6}{*}{$7.7 \%$} & \multirow{4}{*}{190} & 218 & 72.10 & 4138.75 & 9.6 & 8.60 \\
\hline & & & 220 & 72.15 & 4146.40 & 9.5 & 8.50 \\
\hline & & & 222 & 72.20 & 4167.75 & 9.3 & 8.30 \\
\hline & & & 218 & 72.15 & 4166.60 & 9.0 & 8.00 \\
\hline & & \multirow[t]{2}{*}{195} & 220 & 72.25 & 4193.85 & 9.0 & 8.50 \\
\hline & & & 222 & 72.00 & 4244.90 & 9.0 & 8.00 \\
\hline \multirow{6}{*}{3} & \multirow{6}{*}{$5.2 \%$} & \multirow{3}{*}{190} & 218 & 74.15 & 4267.60 & 6.8 & 5.80 \\
\hline & & & 220 & 73.80 & 4282.90 & 6.8 & 5.80 \\
\hline & & & 222 & 73.85 & 4389.25 & 6.8 & 5.80 \\
\hline & & \multirow{3}{*}{195} & 218 & 74.15 & 4403.45 & 6.8 & 5.80 \\
\hline & & & 220 & 74.40 & 4423.10 & 6.8 & 5.80 \\
\hline & & & 222 & 74.35 & 4444.36 & 6.8 & 5.00 \\
\hline \multicolumn{8}{|c|}{$\begin{array}{c}\text { TABLE } 8 . \\
\text { TITER DOA VARIANCE ANALYSIS }\end{array}$} \\
\hline & \multirow[t]{8}{*}{ Variation } & Source & $\mathrm{dk}$ & $\mathrm{Jk}$ & $\mathrm{kt}$ & $\mathrm{F}_{\text {anova }}$ & $\mathrm{P}_{\text {anova }}$ \\
\hline & & $\mathrm{C}_{16}$ & 2 & 727.732 & 363.866 & 19551.00 & 0.000 \\
\hline & & T. Precut & 1 & 5.840 & 5.840 & 313.81 & 0.000 \\
\hline & & B. MD & 2 & 0.127 & 0.063 & 3.40 & 0.056 \\
\hline & & $\mathrm{C}_{16} * \mathrm{~T}$ Precut & 2 & 3.527 & 1.764 & 94.76 & 0.000 \\
\hline & & $\mathrm{C}_{16} * \mathrm{~B} \mathrm{MD}$ & 4 & 0.407 & 0.102 & 5.46 & 0.005 \\
\hline & & T. Precut* B.MD & 2 & 0.216 & 0.108 & 5.79 & 0.011 \\
\hline & & $\mathrm{C}_{16}$ *T. Precut*B.MD & 4 & 0.444 & 0.111 & 5.97 & 0.003 \\
\hline & Error & & 18 & 0.335 & 0.019 & & \\
\hline & Total & & 35 & & & & \\
\hline
\end{tabular}


IPTEK, The Journal for Technology and Science, Vol. 21, No. 4, November 2010

TABLE 9.

Signification of Process VARIABle to Titer DoA

\begin{tabular}{clcll}
\hline NO & Source & $\mathrm{P}_{\text {anova }}$ & Signification & Remarks \\
\hline 1 & $\mathrm{C}_{16}$ & 0.000 & significant & $\mathrm{P}_{\text {anova }}<\mathrm{P} \alpha$ \\
2 & T. Precut & 0.000 & significant & $\mathrm{P}_{\text {anova }}<\mathrm{P} \alpha$ \\
3 & B. MD & 0.056 & notsignificant & $\mathrm{P}_{\text {anova }}>\mathrm{P} \alpha$ \\
4 & $\mathrm{C}_{16} *$ T Precut & 0.000 & significant & $\mathrm{P}_{\text {anova }}<\mathrm{P} \alpha$ \\
5 & $\mathrm{C}_{16} * \mathrm{~B}$ MD & 0.005 & significant & $\mathrm{P}_{\text {anova }}<\mathrm{P} \alpha$ \\
6 & T. Precut $*$ B.MD & 0.011 & significant & $\mathrm{P}_{\text {anova }}<\mathrm{P} \alpha$ \\
7 & C $_{16}$ *T. Precut $*$ B.MD & 0.003 & significant & $\mathrm{P}_{\text {anova }}<\mathrm{P} \alpha$ \\
\hline
\end{tabular}

TABLE 10.

MeAn Titer DOA $\left({ }^{\circ} \mathrm{C}\right)$ AS EFFECTOFINTERACTION C16 FEED AND T PRECUT

\begin{tabular}{|c|c|c|c|}
\hline & \multicolumn{3}{|c|}{ On the top temperatureprecut column $\left(190^{\circ} \mathrm{C}\right)$} \\
\hline & $\mathrm{C} 16,10.5 \%$ & $\mathrm{C} 16,7.7 \%$ & $\mathrm{C} 16,5.2 \%$ \\
\hline \multirow[t]{4}{*}{1} & 18.067 & 9.467 & 6.8 \\
\hline & StDev $=0.216$ & StDev $=0.273$ & StDev $=0.00$ \\
\hline & $\mathrm{F}_{\mathrm{anova}}=5143.0$ & \multicolumn{2}{|c|}{$\mathrm{P}_{\text {anova }}=0.000$} \\
\hline & \multicolumn{3}{|c|}{ On the top temperatureprecutcolumn $\left(195^{\circ} \mathrm{C}\right)$} \\
\hline \multirow[t]{3}{*}{2} & 16.3833 & 9.0 & 6.8 \\
\hline & StDev $=0.1169$ & StDev $=0.000$ & StDev $=0.00$ \\
\hline & $\mathrm{F}_{\mathrm{anova}}=33188$ & \multicolumn{2}{|c|}{$P_{\text {anova }}=0.000$} \\
\hline
\end{tabular}

Note: StDev = standard deviation

TABLE 11.

MeAn Titer DOA $\left({ }^{\circ} \mathrm{C}\right)$ As EFFECT INTERACTION OF $\mathrm{C}_{16}$ FEED AND BMD

\begin{tabular}{|c|c|c|c|}
\hline \multirow[t]{2}{*}{ No } & \multicolumn{3}{|c|}{ On The Bottom Temperature Main Distiller $218^{\circ} \mathrm{C}$} \\
\hline & $\mathrm{C} 16,10.5 \%$ & $\mathrm{C} 16,7.7 \%$ & $\mathrm{C} 16,5.2 \%$ \\
\hline \multirow[t]{4}{*}{1} & 17.175 & 9.3 & 6.8 \\
\hline & StDev $=0,78$ & StDev $=0,383$ & StDev $=0.000$ \\
\hline & $\mathrm{F}_{\text {anova }}=465.46$ & \multicolumn{2}{|c|}{$\mathrm{P}_{\text {anova }}=0.000$} \\
\hline & \multicolumn{3}{|c|}{ On The Bottom Temperature Main Distiller $220^{\circ} \mathrm{C}$} \\
\hline \multirow[t]{4}{*}{2} & 17.175 & 9.25 & 6.8 \\
\hline & $\mathrm{StDev}=1,014$ & StDev $=0,379$ & StDev $=0.000$ \\
\hline & $\mathrm{F}_{\text {anova }}=300,98$ & \multicolumn{2}{|c|}{$\mathrm{P}_{\text {anova }}=0.000$} \\
\hline & \multicolumn{3}{|c|}{ On The Bottom Temperature Main Distiller $222^{\circ} \mathrm{C}$} \\
\hline \multirow[t]{3}{*}{3} & 17.325 & 9.15 & 6.8 \\
\hline & $\mathrm{StDev}=1.13$ & StDev $=0.191$ & StDev $=0.000$ \\
\hline & $F_{\text {anova }}=279.05$ & \multicolumn{2}{|c|}{$\mathrm{P}_{\text {anova }}=0.000$} \\
\hline
\end{tabular}

Note: StDev $=$ standard deviation

TABLE 12.

VARIANCE ANALYSIS OF CLOUd POINT DOA

\begin{tabular}{llccccc}
\hline \multicolumn{1}{c}{ Source } & $\mathrm{D}_{\mathrm{k}}$ & $\mathrm{j}_{\mathrm{k}}$ & $\mathrm{k}_{\mathrm{t}}$ & $\mathrm{F}_{\text {anova }}$ & $\mathrm{P}_{\text {anova }}$ \\
\hline & & 2 & 469.429 & 234.714 & 8284.04 & 0.000 \\
& $\mathrm{C}_{16}$ & 1 & 9.000 & 9.000 & 319.65 & 0.000 \\
& T. Precut & 2 & 0.267 & 0.134 & 4.72 & 0.023 \\
& B. MD & 2 & 9.247 & 0.623 & 163.18 & 0.000 \\
& $\mathrm{C}_{16}$ * T Precut & 4 & 0.451 & 0.113 & 3.98 & 0.017 \\
& $\mathrm{C}_{16}$ * B MD & 2 & 0.302 & 0.151 & 5.32 & 0.015 \\
& T. Precut * B.MD & 4 & 0.407 & 0.102 & 3.59 & 0.026 \\
\hline Error & C $_{16}$ *T. Precut *B.MD & 18 & 0.510 & 0.028 & & \\
Total & & 35 & & & & \\
\hline
\end{tabular}

TABLE 13.

Significationof Process Variables to Cloud Point Doa

\begin{tabular}{cllcl}
\hline NO & \multicolumn{1}{c}{ Sources } & $\mathrm{P}_{\text {anova }}$ & Signification & Remarks \\
\hline 1 & $\mathrm{C}_{16}$ & 0.000 & significant & $\mathrm{P}_{\text {anova }}<\mathrm{P} \alpha$ \\
2 & T. Precut & 0.000 & significant & $\mathrm{P}_{\text {anova }}<\mathrm{P} \alpha$ \\
3 & B. MD & 0.023 & significant & $\mathrm{P}_{\text {anova }}<\mathrm{P} \alpha$ \\
4 & $\mathrm{C}_{16} * \mathrm{~T}$ Precut & 0.000 & significant & $\mathrm{P}_{\text {anova }}<\mathrm{P} \alpha$ \\
5 & $\mathrm{C}_{16}$ * B MD & 0.017 & significant & $\mathrm{P}_{\text {anova }}<\mathrm{P} \alpha$ \\
6 & T. Precut $*$ B.MD & 0.015 & significant & $\mathrm{P}_{\text {anova }}<\mathrm{P} \alpha$ \\
7 & $\mathrm{C}_{16}$ *T. Precut *B.MD & 0.026 & significant & $\mathrm{P}_{\text {anova }}<\mathrm{P} \alpha$ \\
\hline
\end{tabular}


IPTEK, The Journal for Technology and Science, Vol. 21, No. 4, November 2010

TABLE 14.

Mean Cloud Point DoA $\left({ }^{\circ} \mathrm{C}\right)$ As InTERACtion EFFect of $\mathrm{C}_{16}$ FeEd And T Precut

\begin{tabular}{|c|c|c|c|}
\hline \multirow[t]{2}{*}{ No } & \multicolumn{3}{|c|}{ On Top Temperaturof Precut Column $190^{\circ} \mathrm{C}$} \\
\hline & $\mathrm{C} 16,10.5 \%$ & $\mathrm{C} 16,7.7 \%$ & $\mathrm{C} 16,5.2 \%$ \\
\hline \multirow[t]{4}{*}{1} & 15.967 & 8.467 & 5.80 \\
\hline & StDev $=1.244$ & StDev $=0.273$ & StDev $=0,00$ \\
\hline & \multicolumn{3}{|c|}{$\mathrm{P}$ anova $=0.000$} \\
\hline & \multicolumn{3}{|c|}{ On Top Temperature Of Precut Column $195{ }^{\circ} \mathrm{C}$} \\
\hline \multirow[t]{3}{*}{2} & 13.083 & 8.167 & 5.533 \\
\hline & StDev $=0.117$ & StDev $=0.320$ & StDev $=0.00$ \\
\hline & $\mathrm{F}_{\text {anova }}$ & \multicolumn{2}{|c|}{$\mathrm{P}$ anova $=0.000$} \\
\hline
\end{tabular}

Note: StDev $=$ standard deviation

TABLE 15.

Mean Cloud Point DoA $\left({ }^{\circ} \mathrm{C}\right)$ As InTERACTION EFFECT OF $\mathrm{C}_{16}$ FeEd And BmD

\begin{tabular}{|c|c|c|c|}
\hline \multirow[t]{2}{*}{ No } & \multicolumn{3}{|c|}{ On The Bottom Temperaturemain Distiller $218^{\circ} \mathrm{C}$} \\
\hline & $\mathrm{C} 16,10.5 \%$ & $\mathrm{C} 16,7.7 \%$ & $\mathrm{C} 16,5.2 \%$ \\
\hline \multirow[t]{4}{*}{1} & 14.30 & 8.30 & 5.80 \\
\hline & StDev $=1.244$ & StDev $=0.273$ & StDev $=0.000$ \\
\hline & $F_{\text {anova }}=129.62$ & \multicolumn{2}{|c|}{$\mathrm{P}_{\mathrm{anova}}=0.000$} \\
\hline & \multicolumn{3}{|c|}{ On The Bottom Temperaturemain Distiller $220^{\circ} \mathrm{C}$} \\
\hline \multirow[t]{4}{*}{2} & 14.255 & 8.50 & 5.80 \\
\hline & StDev $=1.415$ & StDev $=0.346$ & StDev $=0.000$ \\
\hline & $\mathrm{F}_{\text {anova }}=10.64$ & \multicolumn{2}{|c|}{$\mathrm{P}_{\text {anova }}=0.000$} \\
\hline & \multicolumn{3}{|c|}{ On The Bottom Temperaturemain Distiller $222^{\circ} \mathrm{C}$} \\
\hline \multirow[t]{2}{*}{3} & 15.05 & 8.15 & 5.4 \\
\hline & $\begin{array}{l}\text { StDev }=2.596 \\
F_{\text {anova }}=42.45\end{array}$ & $\begin{array}{r}\text { StDev }=0.191 \\
P_{\text {anova }}\end{array}$ & StDev $=0.642$ \\
\hline
\end{tabular}

Note: $\mathrm{StDev}=$ standard deviation

TABLE 16.

COMPARATION OF DISTILLATION OPERATING CONDITIONS

\begin{tabular}{llll}
\hline No & $\begin{array}{l}\text { Controlled Operating } \\
\text { Conditions } \\
\text { Parameters }\end{array}$ & $\begin{array}{l}\text { Before } \\
\text { Optimization }\end{array}$ & $\begin{array}{l}\text { After } \\
\text { Optimization }\end{array}$ \\
\hline 1 & Feed flow rate $(\mathrm{mt} /$ hours $)$ & 4.0 & 5.0 \\
2 & Top temperature precut column $\left({ }^{\circ} \mathrm{C}\right)$ & $216-219$ & 195 \\
3 & Top pressure precut column, mbar & $21-25$ & $15-21$ \\
4 & Light end yield, $\% /(\mathrm{kg} /$ hours $)(*)$ & $8.7 / 348$ & $2.801 / 140.05$ \\
5 & Bottom temperature MD column $\left({ }^{\circ} \mathrm{C}\right)$ & $246-249$ & 222 \\
6 & Top pressure MD column $(\mathrm{mbar}$ & $10-12$ & 5.0 \\
7 & DOAyield $(\% /(\mathrm{kg} / \mathrm{hours})(*)$ & $84.0 / 3360$ & $88.34 / 4416.8$ \\
8 & Residue yield $(\% /(\mathrm{kg} / \mathrm{hours}))(*)$ & $7.3 / 292$ & $9.18 / 459.13$ \\
\hline
\end{tabular}

Notes: (*) Example: after optimization is achieved DOA yield at $88.34 \%$ of feed rate or $4416.8 \mathrm{~kg} / \mathrm{hours}$

TABLE 17.

COMPARATION DOA QUALITY BEFORE AND AFTER OPTIMIZATION

\begin{tabular}{lllll}
\hline No & Quality Parameter & $\begin{array}{l}\text { Quality Standard } \\
\text { DOA }\end{array}$ & $\begin{array}{l}\text { DOA Quality } \\
\text { before } \\
\text { Optimization }(*)\end{array}$ & $\begin{array}{l}\text { DOA Quality } \\
\text { after } \\
\text { Optimization }\end{array}$ \\
\hline 1 & Composition $(\% \mathrm{w} / \mathrm{w})$ & & 74.40 \\
& $\mathrm{C}_{18-1}$, oleic acid & $70 \mathrm{~min}$ & 71.1 & 6.8 \\
2 & Titer $\left({ }^{\circ} \mathrm{C}\right)$ & $10 \max$ & 12.7 & 5.0 \\
\hline
\end{tabular}

Note: $(*)$, DOA quality before blended with lauricacid $\mathrm{C}_{12}$ and myristicacid $\mathrm{C}_{14}$ 
IPTEK, The Journal for Technology and Science, Vol. 21, No. 4, November 2010

Main effects plot for means titer DOA

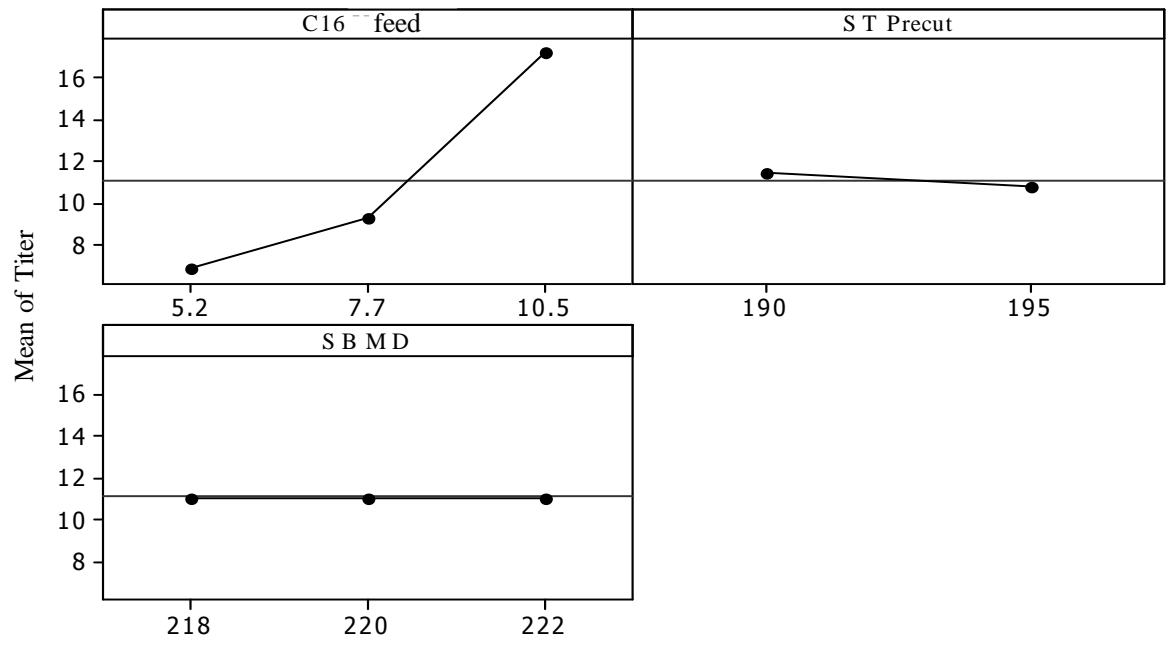

Fig. 3. Graphic of the main effects of the main factors to the titer DOA $\left({ }^{\circ} \mathrm{C}\right)$

Interaction plot for means of titer DOA

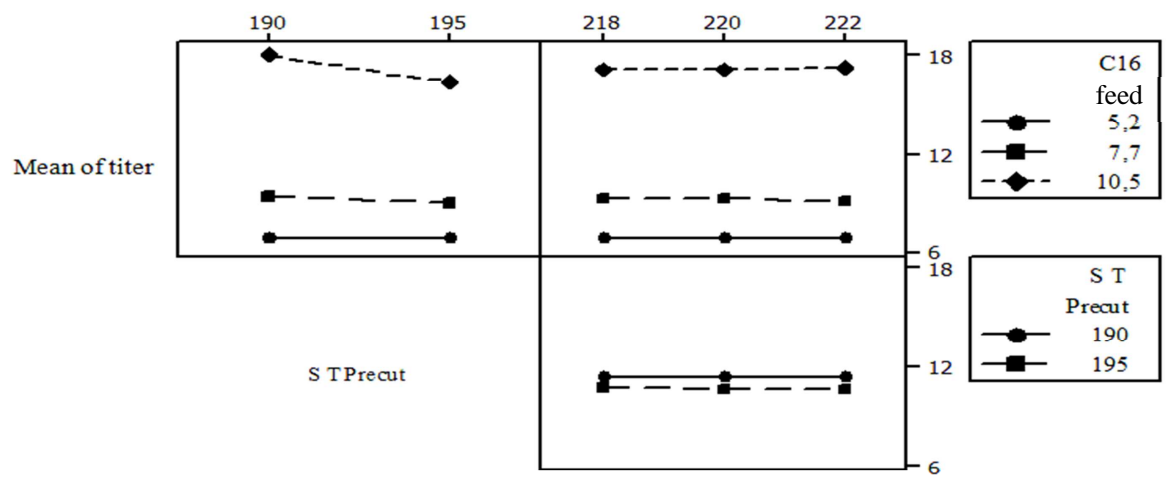

S B MD

Fig. 4. Graphic of effect of the main factors interaction to thetiter DOA $\left({ }^{\circ} \mathrm{C}\right)$

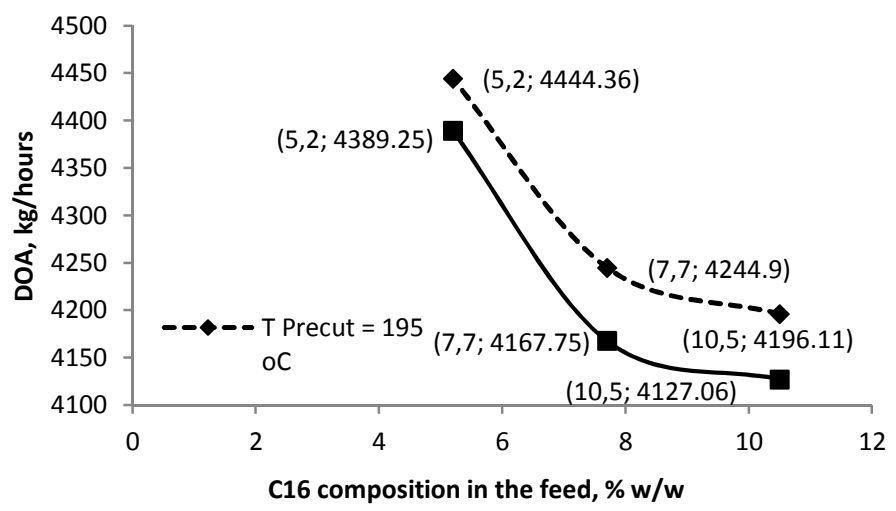

Fig. 5. Effect of $\mathrm{C} 16$ composition in the feed to the increment of DOA rate on the top temperature precut column 190 and $195{ }^{\circ} \mathrm{C}$ 


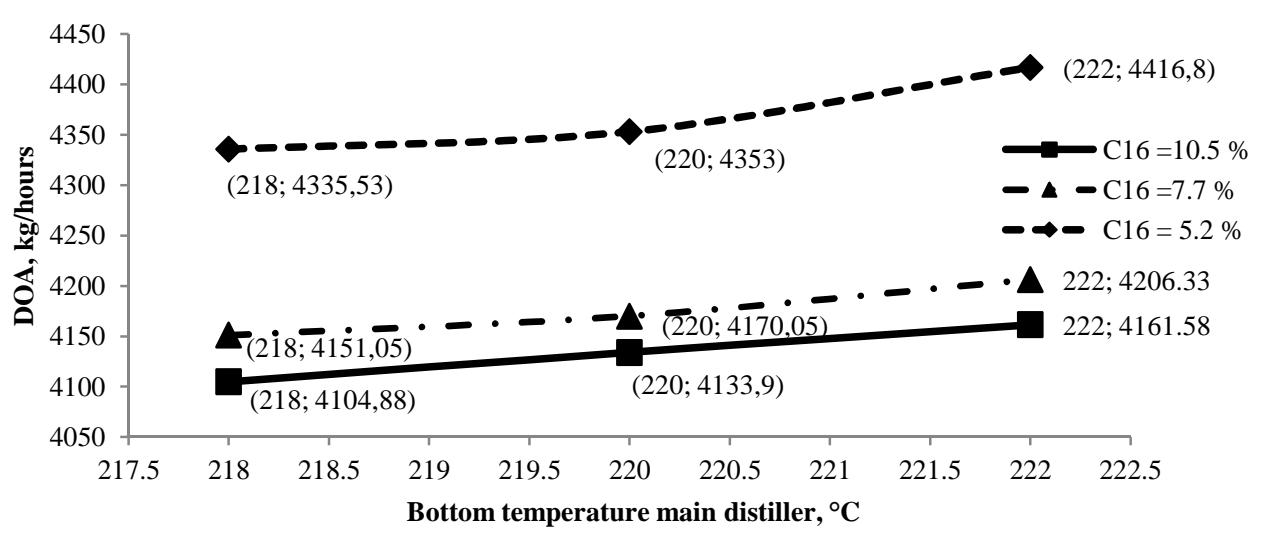

Fig. 6. Effect of temperature bottom temperature main distiller to DOA rate

Main effects plot for means of cloud point DOA

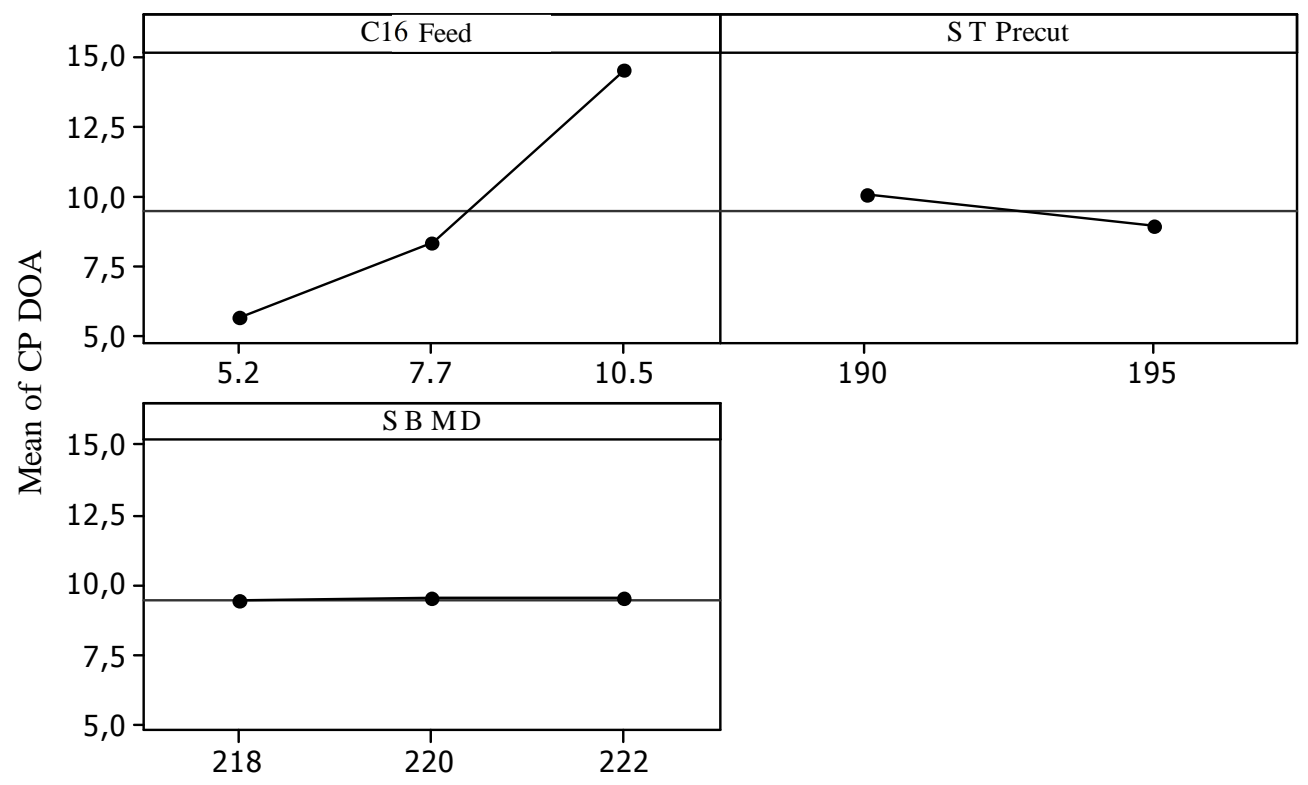

Fig. 7. Graphic of the main effect of the main factors to thecloud point DOA $\left({ }^{\circ} \mathrm{C}\right)$

Interaction plot for means of cloud point DOA

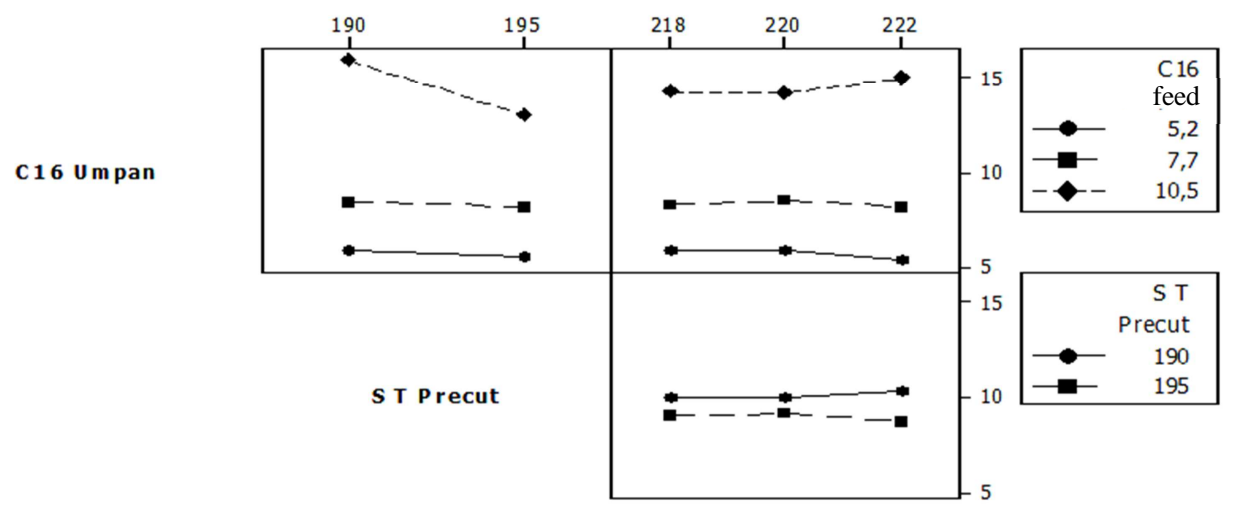

Fig. 8. Graphic of effect of the main factors interaction to the cloud point $\mathrm{DOA}\left({ }^{\circ} \mathrm{C}\right)$ 
IPTEK, The Journal for Technology and Science, Vol. 21, No. 4, November 2010

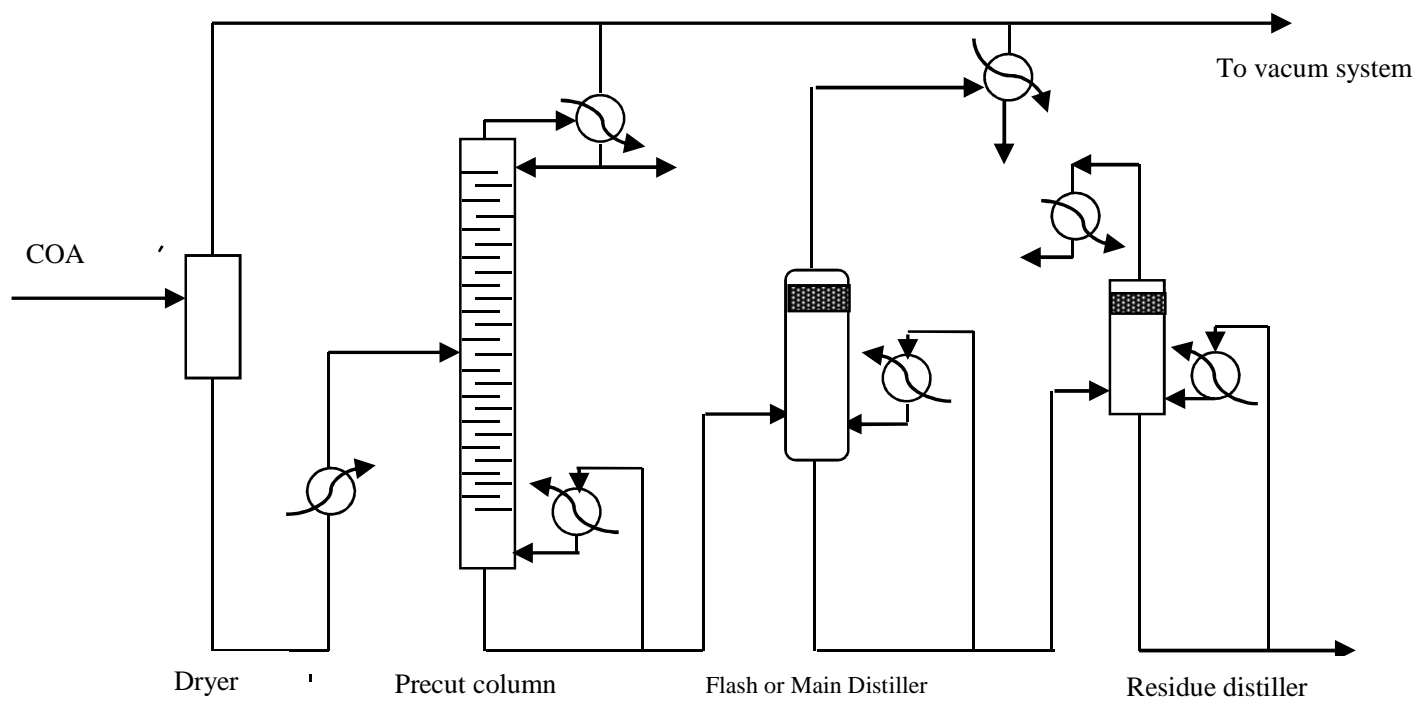

Fig. 9. Flowchart of the presents facility oleic acid distillation

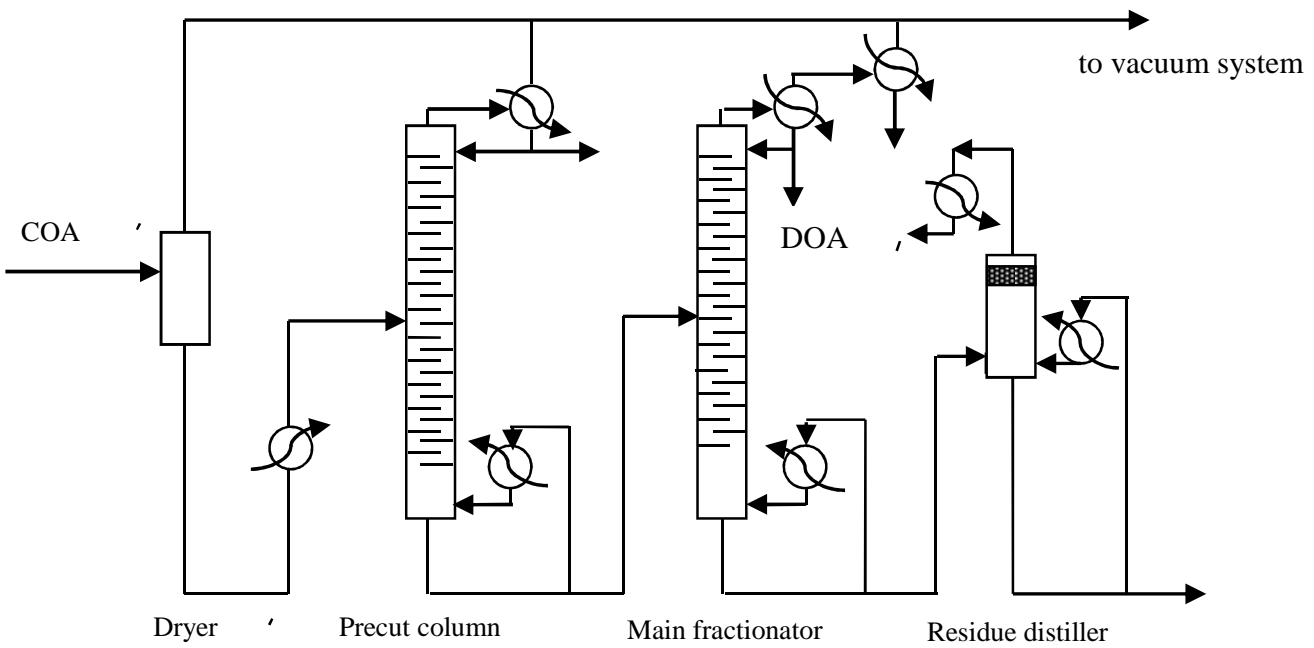

Fig. 10. An idea to modify the presents facility oleic acid distillation 
IPTEK, The Journal for Technology and Science, Vol. 21, No. 4, November 2010 